\title{
Differences in the number of hemocytes in the snail host Biomphalaria tenagophila, resistant and susceptible to Schistosoma mansoni infection
}

\author{
A.L.D. Oliveira ${ }^{1,4,5}$, P.M. Levada ${ }^{2}$, E.M. Zanotti-Magalhaes ${ }^{3}$, \\ L.A. Magalhães ${ }^{3}$ and J.T. Ribeiro-Paes ${ }^{2}$ \\ ${ }^{1}$ Programa de Pós-Graduação Interunidades em Biotecnologia, USP, IPT, \\ Instituto Butantan, São Paulo, SP, Brasil \\ ${ }^{2}$ Departamento de Ciências Biológicas, Universidade Estadual Paulista, \\ Assis, SP, Brasil \\ ${ }^{3}$ Departamento de Parasitologia, Instituto de Biologia, \\ Universidade Estadual de Campinas, Campinas, SP, Brasil \\ ${ }^{4}$ Departamento de Saúde, ADR, Biomavale, Assis, SP, Brasil \\ ${ }^{5}$ Departamento de Ciências da Saúde, Universidade Paulista, Assis, SP, Brasil
}

Corresponding author: J.T. Ribeiro-Paes

E-mail: jtrpaes@yahoo.com.br

Genet. Mol. Res. 9 (4): 2436-2445 (2010)

Received November 5, 2010

Accepted November 12, 2010

Published December 21, 2010

DOI 10.4238/vol9-4gmr1143

\begin{abstract}
The relationships between schistosomiasis and its intermediate host, mollusks of the genus Biomphalaria, have been a concern for decades. It is known that the vector mollusk shows different susceptibility against parasite infection, whose occurrence depends on the interaction between the forms of trematode larvae and the host defense cells. These cells are called amebocytes or hemocytes and are responsible for the recognition of foreign bodies and for phagocytosis and cytotoxic reactions. The defense cells mediate the modulation of the resistant and susceptible phenotypes of the mollusk. Two main types of hemocytes are found in the Biomphalaria hemolymph: the granulocytes and the hyalinocytes. We studied the variation in the number (kinetics) of hemocytes for $24 \mathrm{~h}$ after exposing the parasite to genetically selected and non-selected strains of
\end{abstract}


Biomphalaria tenagophila, susceptible or not to infection by Schistosoma mansoni. The differences were analyzed referred to the variations in the number of hemocytes in mollusks susceptible or not to infection by $S$. mansoni. The hemolymph of the selected and non-selected snails was collected, and hemocytes were counted using a Neubauer chamber at six designated periods: $0 \mathrm{~h}$ (control, non-exposed individuals), $2 \mathrm{~h}, 6 \mathrm{~h}, 12$ $\mathrm{h}, 18 \mathrm{~h}$ and, $24 \mathrm{~h}$ after parasite exposure. Samples of hemolymph of five selected mollusks and five non-selected mollusks were separately used at each counting time. There was a significant variation in the number of hemocytes between the strains, which indicates that defense cells have different behaviors in resistant and susceptible mollusks.

Key words: Biomphalaria tenagophila; Schistosoma mansoni; Hemocyte behavior; Schistosomiasis; Biological control

\section{INTRODUCTION}

Schistosomiasis, a parasitic disease caused by a trematode of the genus Schistosoma, is pointed out as one of the most serious and outstanding public health problems worldwide, with 200 million infected individuals and 600 million living in risk areas in 76 countries, mainly in tropical and subtropical regions (WHO, 2008).

The schistosomiasis vector mollusks, genus Biomphalaria, show different levels of susceptibility to infection by Schistosoma mansoni (Ruiz, 1957; Paraense and Corrêa, 1963, 1978; Mascara et al., 1999). Susceptibility may vary in relation to geographic areas, the local population, individuals, and individuals of different ages (Richards, 1984). In addition, some external and internal factors may play a role in the number of cercariae produced by the host snail. Among these factors, temperature, nutritional condition of the host snail, time life of the mollusk (Frandsen, 1979), and size of the snail (Richards, 1984) are pointed out, in addition to genetic differences in the parasite population (Richards et al., 1992).

Until recently, little was known about the modulation of the resistant and susceptible phenotypes, as well as about the origin of the physiological mechanism of defense of the mollusk genus Biomphalaria. Nowadays, it is known that cells in the hemolymph and in the body fluids mediate this defense system. These cells are called amebocytes or hemocytes (Ratcliffe, 1985), which are responsible for the recognition of foreign bodies, for encapsulation responses, and for phagocytosis and cytotoxic reactions (Allegretti, 1991; Yoshino et al., 2001). Two main types of hemocytes are found in the Biomphalaria hemolymph: the granulocytes, cells with pseudopods are capable of phagocytosis and encapsulation, and the hyalinocytes, more spherical and smaller cells, are without pseudopods (Ratcliffe, 1985).

Some authors suggest that the hyalinocytes and the granulocytes are distinct cell types, while others consider that they represent different developmental phases of the same cell type. Seasonal factors and diverse experimental physiological conditions affect the total number, type and behavior of the hemocytes (Oliver and Fisher, 1995). In this way, the number of hemocytes may vary according to certain stimuli, such as responses to infection by trematodes (Sullivan et al., 1984). The study of the hemocytes has been considered extremely important for understanding the processes leading to infection, as well as the processes that make the 
mollusks resistant or susceptible to the parasite.

We studied the variation in the number (kinetics) of hemocytes for $24 \mathrm{~h}$ after exposing the parasite to genetically selected and non-selected strains of Biomphalaria tenagophila, susceptible or not to infection by S. mansoni. This species is an important vector of schistosomiasis in Brazilian regions, especially in the southeast and south regions.

\section{MATERIAL AND METHODS}

Biomphalaria tenagophila, genetically selected and non-selected for susceptibility, were used. The selection was carried out by means of fertilization of susceptible parental generation. The non-selected mollusks pertain to natural $B$. tenagophila populations in breeding areas in the Vale do Paraíba do Sul region, São Paulo State, Brazil. The mollusks are maintained in the Laboratory of Schistosomiasis of the Parasitology Department, at UNICAMP (Campinas, São Paulo, Brazil).

The strain of S. mansoni used in this study was SJ, originating from São José dos Campos (São Paulo, Brazil) and kept in the laboratory by means of transfusions with B. tenagophila in Swiss mice. The snails were exposed to $10 \mathrm{SJ}$ miracidia according to the methodology described by Zanotti-Magalhães et al. (1997).

Hemocyte (Figure 1) counts were carried out according to the protocol by ZanottiMagalhães et al. (1997), using a Neubauer chamber. Counts were done at 6 designated times: $0 \mathrm{~h}$ (for non-exposed individuals), $2 \mathrm{~h}, 6 \mathrm{~h}, 12 \mathrm{~h}, 18 \mathrm{~h}$, and $24 \mathrm{~h}$ after exposing the snail to miracidia. Samples of hemolymph of five selected mollusks and five non-selected mollusks were separately used at each counting time. The hemolymph was collected by means of a puncture of about $7 \mathrm{~mm}$ in the snail cephalopodal region.

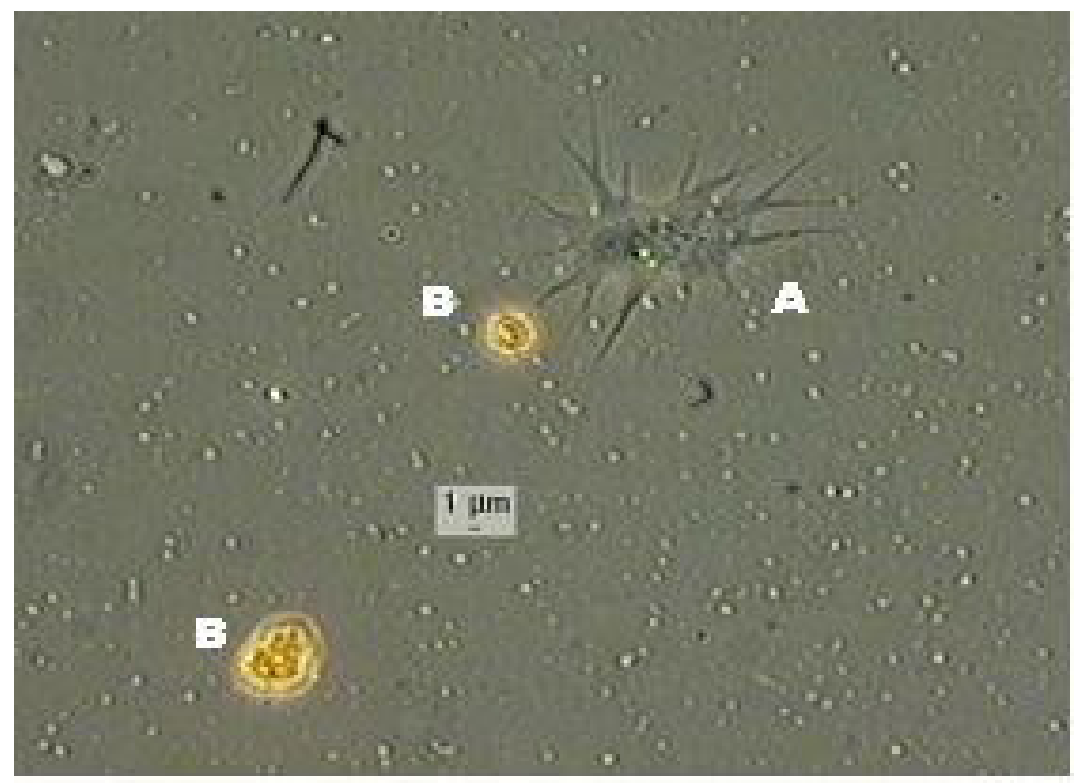

Figure 1. Types of hemocytes in hemolymph observed by phase contrast microscopy (400X). A. Granulocytes. B. Hyalinocytes. 
Statistical analysis of data was carried out by means of Friedman and Mann-Whitney U-non-parametric tests. Variance analysis of the hemocyte number among the counting times for non-selected and genetically selected snails for susceptibility was carried out using the Friedman non-parametric test for dependent samples at the 5\% level of significance.

Comparisons between the non-selected and genetically selected snails for susceptibility with regard to hemocyte numbers were made using the Mann-Whitney U-non-parametric test for independent samples, at the 5\% level of significance.

\section{RESULTS}

According to the hemocyte counting intervals, the data obtained revealed statistically significant differences (Tables 1, 2 and 3).

Tables 1 and 2 present the Friedman test results relative to the variation of the total numbers of hemocytes and of granulocytes, respectively, in the non-selected and genetically selected snails for susceptibility. The data show that there is a significant difference between the times for both strains of snails. Table 3, which presents the resulting data of the Friedman test for the variation in the number of hyalinocytes in selected and non-selected mollusks, indicates that there was no statistically significant difference between the sampling times for this cell type in selected and in non-selected individuals, as well. Data variation was considered to be statistically significant with a significance level of 0.01407 for the total number of hemocytes of the snails selected for susceptibility, and 0.3024 for the total number of hemocytes of the non-selected snails.

Table 1. Variation in the total number of hemocytes $24 \mathrm{~h}$ after the exposition to the miracidia in snails genetically selected and non-selected for susceptibility, according to the Friedman test.

\begin{tabular}{rcccccc}
\hline & \multicolumn{3}{c}{ Selected } & & \multicolumn{2}{c}{ Non-selected } \\
\cline { 2 - 4 } & Miracidia & $\mathrm{N}$ & Friedman test & & Miracidia & N \\
\hline $0 \mathrm{~h}$ & $44^{\mathrm{b}}$ & 5 & 14.2571 & $48^{\mathrm{a}}$ & 5 & 12.3563 \\
$2 \mathrm{~h}$ & $35^{\mathrm{a}}$ & 5 & 14.2571 & $29^{\mathrm{b}}$ & 5 & 12.3563 \\
$6 \mathrm{~h}$ & $65^{\mathrm{b}}$ & 5 & 14.2571 & $45^{\mathrm{a}}$ & 5 & 12.3563 \\
$12 \mathrm{~h}$ & $59^{\mathrm{b}}$ & 5 & 14.2571 & $30^{\mathrm{b}}$ & 5 & 12.3563 \\
$18 \mathrm{~h}$ & $48^{\mathrm{b}}$ & 5 & 14.2571 & $35^{\mathrm{ab}}$ & 5 & 12.3563 \\
$24 \mathrm{~h}$ & $55^{\mathrm{b}}$ & 5 & 14.2571 & $62^{\mathrm{a}}$ & 5 & 12.3563 \\
\hline
\end{tabular}

Same superscript letters in the columns indicate values with non-significant differences between them $(\mathrm{P}<0.05)$.

Table 2. Variation in the number of granulocytes $24 \mathrm{~h}$ after the exposition to the miracidia in snails genetically selected and non-selected for susceptibility, according to the Friedman test.

\begin{tabular}{|c|c|c|c|c|c|c|}
\hline & \multicolumn{3}{|c|}{ Selected } & \multicolumn{3}{|c|}{ Non-selected } \\
\hline & Miracidia & $\mathrm{N}$ & Friedman test & Miracidia & $\mathrm{N}$ & Friedman test \\
\hline $0 \mathrm{~h}$ & $32^{\mathrm{b}}$ & 5 & 11.37931 & $30^{\mathrm{a}}$ & 5 & 13.2184 \\
\hline $2 \mathrm{~h}$ & $18^{\mathrm{a}}$ & 5 & 11.37931 & $18^{\mathrm{b}}$ & 5 & 13.2184 \\
\hline $6 \mathrm{~h}$ & $47^{\mathrm{b}}$ & 5 & 11.37931 & $15^{\mathrm{b}}$ & 5 & 13.2184 \\
\hline $12 \mathrm{~h}$ & $38^{\mathrm{b}}$ & 5 & 11.37931 & $16^{\mathrm{b}}$ & 5 & 13.2184 \\
\hline $18 \mathrm{~h}$ & $36^{\mathrm{b}}$ & 5 & 11.37931 & $24^{\mathrm{ab}}$ & 5 & 13.2184 \\
\hline $24 \mathrm{~h}$ & $36^{\mathrm{b}}$ & 5 & 11.37931 & $36^{\text {ac }}$ & 5 & 13.2184 \\
\hline
\end{tabular}

Same superscript letters in the columns indicate values with non-significant differences between them $(\mathrm{P}<0.05)$. 
Table 3. Variation in the number of hyalinocytes in snails genetically selected and non-selected for susceptibility $24 \mathrm{~h}$ after the exposition to the miracidia, according to the Friedman test.

\begin{tabular}{|c|c|c|c|c|c|c|}
\hline & \multicolumn{3}{|c|}{ Selected } & \multicolumn{3}{|c|}{ Non-selected } \\
\hline & Miracidia & $\mathrm{N}$ & Friedman test & Miracidia & $\mathrm{N}$ & Friedman test \\
\hline $0 \mathrm{~h}$ & $13^{\mathrm{a}}$ & 5 & 9.0294 & $18^{\mathrm{a}}$ & 5 & 5.8579 \\
\hline $2 \mathrm{~h}$ & $16^{\mathrm{a}}$ & 5 & 9.0294 & $16^{\mathrm{a}}$ & 5 & 5.8579 \\
\hline $6 \mathrm{~h}$ & $17^{\mathrm{a}}$ & 5 & 9.0294 & $21^{\mathrm{a}}$ & 5 & 5.8579 \\
\hline $12 \mathrm{~h}$ & $19^{\mathrm{a}}$ & 5 & 9.0294 & $17^{\mathrm{a}}$ & 5 & 5.8579 \\
\hline $18 \mathrm{~h}$ & $12^{\mathrm{a}}$ & 5 & 9.0294 & $16^{\mathrm{a}}$ & 5 & 5,8579 \\
\hline $24 \mathrm{~h}$ & $18^{\mathrm{a}}$ & 5 & 9.0294 & $24^{\mathrm{a}}$ & 5 & 5.8579 \\
\hline
\end{tabular}

Same superscript letters in the columns indicate values with non-significant differences between them $(\mathrm{P}<0.05)$.

The Friedman test also revealed significance levels of 0.04438 for granulocytes of the snails selected for susceptibility and of 0.02143 for granulocytes of the mollusks non-selected for susceptibility. The variation in the number of hyalinocytes was not considered to be statistically significant; the level of significance for the selected individuals was 0.10793 , and for the non-selected ones 0.32031 .

The non-parametric Mann-Whitney U-test was used for independent samples. The objective was to check the occurrence of statistically significant differences between the number of hemocytes in the snails genetically selected for susceptibility to the infection by the $S$. mansoni, and the number of hemocytes in the non-selected snails. The results of the Mann-Whitney U-test are presented in Tables 4, 5 and 6.

Table 4. Variation in the total number of hemocytes in snails genetically selected and non-selected for susceptibility $24 \mathrm{~h}$ after the exposition to the miracidia, according to the Mann-Whitney U-test.

\begin{tabular}{rccccc}
\hline & \multicolumn{2}{c}{ Selected } & & \multicolumn{2}{c}{ Non-selected } \\
\cline { 2 - 6 } & Miracidia & $\mathrm{N}$ & Miracidia & N & Mann-Whitney U-test \\
\hline $0 \mathrm{~h}$ & $44^{\text {ns }}$ & 5 & $48^{\text {ns }}$ & 5 & 12.5 \\
$2 \mathrm{~h}$ & $35^{\text {ns }}$ & 5 & $29^{\text {ns }}$ & 5 & 9.5 \\
$6 \mathrm{~h}$ & $65^{*}$ & 5 & $45^{*}$ & 5 & 2 \\
$12 \mathrm{~h}$ & $59^{*}$ & 5 & $30^{*}$ & 5 & 0 \\
$18 \mathrm{~h}$ & $48^{\text {ns }}$ & 5 & $35^{\text {ns }}$ & 5 & 6 \\
$24 \mathrm{~h}$ & $55^{\text {ns }}$ & 5 & $62^{\text {ns }}$ & 5 & 7 \\
\hline
\end{tabular}

ns $=$ non-significant. $*=$ significant $(\mathrm{P}<0.05)$.

Table 5. Variation in the number of granulocytes in snails genetically selected and non-selected for susceptibility $24 \mathrm{~h}$ after the exposition to the miracidia, according to the Mann-Whitney U-test.

\begin{tabular}{rccccc}
\hline & \multicolumn{2}{c}{ Selected } & & \multicolumn{2}{c}{ Non-selected } \\
\cline { 2 - 5 } & Miracidia & $\mathrm{N}$ & Miracidia & N & Mann-Whitney U-test \\
$0 \mathrm{~h}$ & $32^{\mathrm{ns}}$ & 5 & $30^{\mathrm{ns}}$ & 5 & 11 \\
$2 \mathrm{~h}$ & $18^{\mathrm{ns}}$ & 5 & $18^{\mathrm{ns}}$ & 5 & 10 \\
$6 \mathrm{~h}$ & $47^{*}$ & 5 & $15^{*}$ & 5 & 5 \\
$12 \mathrm{~h}$ & $38^{*}$ & 5 & $16^{*}$ & 5 & 0 \\
$18 \mathrm{~h}$ & $36^{\mathrm{ns}}$ & 5 & $24^{\mathrm{ns}}$ & 5 & 4.5 \\
$24 \mathrm{~h}$ & $36^{\mathrm{ns}}$ & 5 & $36^{\mathrm{ns}}$ & 5 & 12 \\
\hline
\end{tabular}

ns $=$ non-significant. $*=$ significant $(\mathrm{P}<0.05)$. 
Table 6. Variation in the number of hyalinocytes in snails genetically selected and non-selected for susceptibility $24 \mathrm{~h}$ after the exposition to the miracidia, according to the Mann-Whitney U-test.

\begin{tabular}{rccccc}
\hline & \multicolumn{2}{c}{ Selected } & \multicolumn{3}{c}{ Non-selected } \\
\cline { 2 - 6 } & Miracidia & $\mathrm{N}$ & Miracidia & $\mathrm{N}$ & Mann-Whitney U-test \\
$0 \mathrm{~h}$ & $13^{\text {ns }}$ & 5 & $18^{\text {ns }}$ & 5 & 11 \\
$2 \mathrm{~h}$ & $16^{\text {ns }}$ & 5 & $16^{\text {ns }}$ & 5 & 11.5 \\
$6 \mathrm{~h}$ & $17^{\text {ns }}$ & 5 & $21^{\text {ns }}$ & 5 & 10.5 \\
$12 \mathrm{~h}$ & $19^{\text {ns }}$ & 5 & $17^{\text {ns }}$ & 5 & 8 \\
$18 \mathrm{~h}$ & $12^{\text {ns }}$ & 5 & $16^{\text {ns }}$ & 5 & 8 \\
$24 \mathrm{~h}$ & $18^{\text {ns }}$ & 5 & & $54^{\text {ns }}$ &
\end{tabular}

At the 5\% level of significance, the difference between the total number of hemocytes of selected and non-selected snails was statistically significant at times $6 \mathrm{~h}$ and $12 \mathrm{~h}$ after exposure to miracidia: 0.02828 for the genetically selected snails and 0.00882 for the non-selected snails. There was no statistically significant difference between the number of hyalinocytes of the selected snails and of the non-selected snails. For the number of granulocytes, there was a significant difference between the two B. tenagophila strains at 6- and 12-h intervals after exposure to miracidia, with levels of significance of 0.012191 for the selected mollusks and 0.009028 for the non-selected mollusks.

Figure 2 shows the average variation in the total hemocyte numbers $24 \mathrm{~h}$ post-exposure to miracidia. In the first $2 \mathrm{~h}$ after exposure, there was a reduction in the number of hemocytes in both strains of $B$. tenagophila. Following that, distinct behavior patterns of these defense cells were observed between the two strains studied. These distinctions are higher for the granulocytes, as shown in Figures 3 and 4, which show a tendency toward a greater number of granulocytes in the hemolymph in the snails genetically selected for susceptibility. As observed in Figure 4, the number of granulocytes increased and then returned to its initial levels between 2 and $6 \mathrm{~h}$ after exposure to the parasite. In the non-selected snails, the number of granulocytes began to increase $12 \mathrm{~h}$ after exposure of the mollusks to the miracidia.

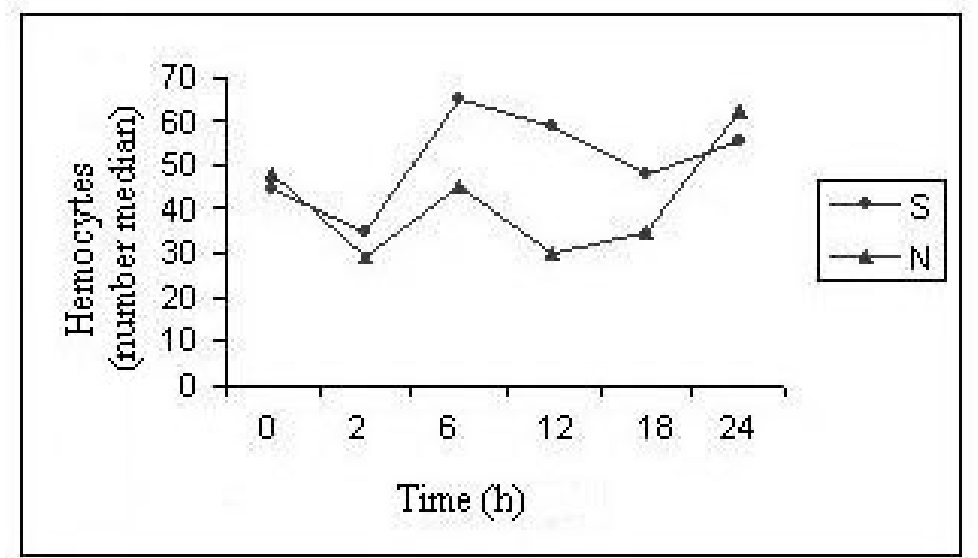

Figure 2. Average variation in the number of hemocytes in Biomphalaria tenagophila snails genetically selected $(\mathrm{S})$ and non-selected (N) for susceptibility to infection by Schistosoma mansoni, $24 \mathrm{~h}$ after exposure to miracidia. 


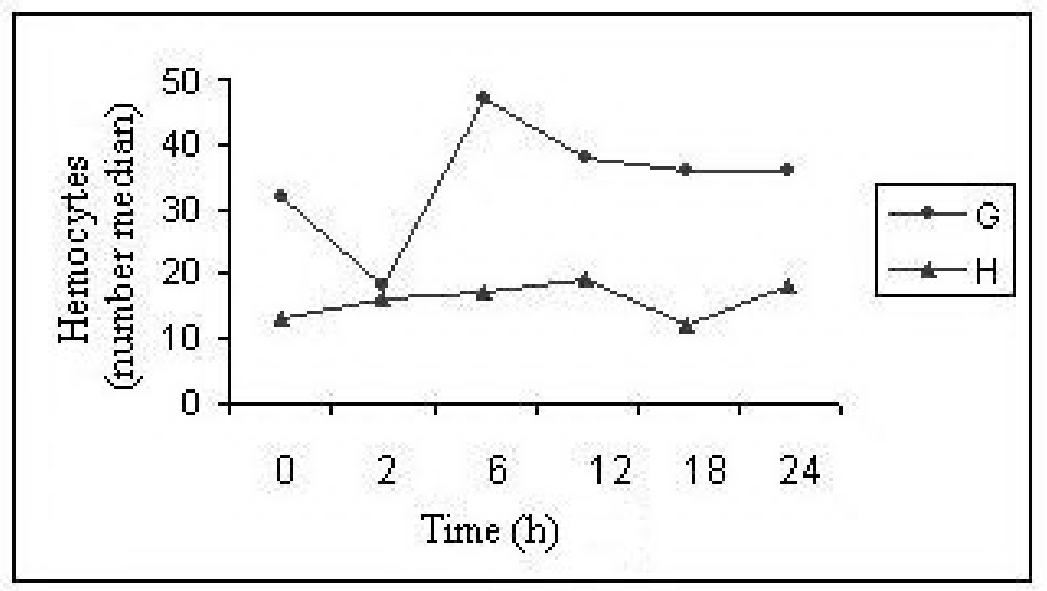

Figure 3. Average variation in the number of hemocytes of the hyalinocyte $(\mathrm{H})$ and granulocyte $(\mathrm{G})$ type in Biomphalaria tenagophila snails genetically selected for susceptibility to infection by Schistosoma mansoni, $24 \mathrm{~h}$ after exposure to miracidia.

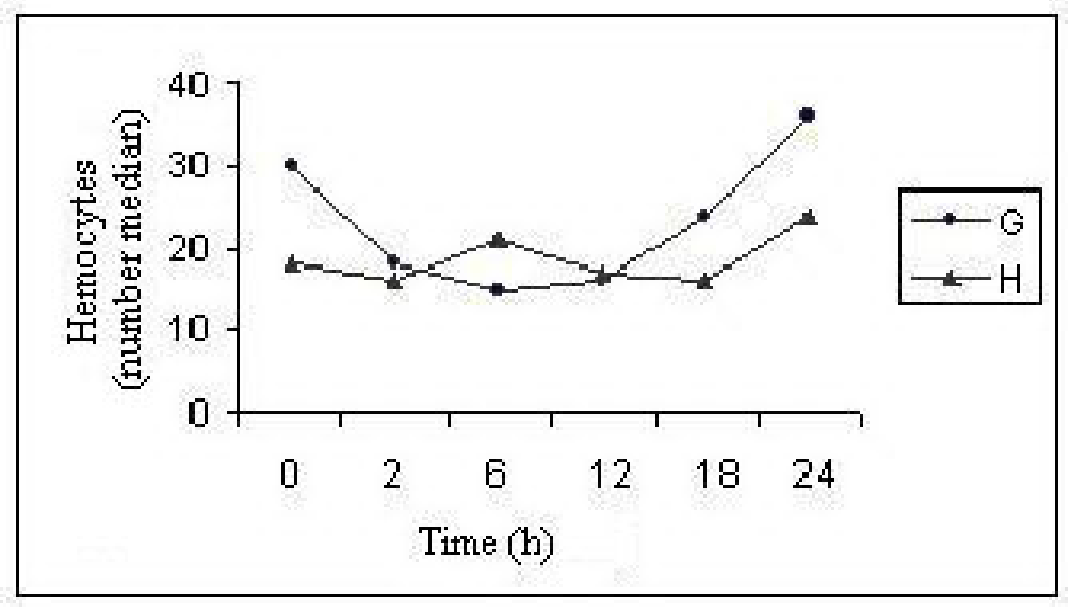

Figure 4. Average variation in the number of hemocytes of the hyalinocyte $(\mathrm{H})$ and granulocyte $(\mathrm{G})$ type in Biomphalaria tenagophila snails genetically non-selected for susceptibility to infection by Schistosoma mansoni, $24 \mathrm{~h}$ after exposure to miracidia.

\section{DISCUSSION}

The data obtained in this study showed statistically significant differences in the number of hemocytes between the two strains of $B$. tenagophila, when exposed to the parasite. These differences indicate a differential behavior that may be related to the resistant or susceptible phenotype. The fact that no statistically significant differences for the hyalinocytes were seen during particular times, as shown in Table 3, is probably related to the immunological capacity of these cells. To date, the phagocytic potential of hyalinocytes is questioned, and only 
granulocytes are described as cells responsible for phagocytosis (Seta et al., 1996). For this reason, variations in the number of granulocytes in the face of infection by parasites are more expected to occur than variations in the number of hyalinocytes. Seta et al. (1996) described a response pattern to infection by $S$. mansoni species-specific for the snail genus $B$. tenagophila. These authors observed an initial peak in the number of hemocytes in infected B. glabrata, whereas in $B$. tenagophila, they reported a decrease in the number of hemocytes in the first $2 \mathrm{~h}$ after infection. The results obtained in this study show a late increase in the number of hemocytes of $B$. tenagophila in response to infection by $S$. mansoni.

The results obtained show that, in the first $2 \mathrm{~h}$ after exposure to the parasite, there was a significant reduction in the number of hemocytes in the hemolymph of both strains of $B$. tenagophila (Figure 2). This event may be related to the migration of these cells toward the infected tissue with the objective of attacking the parasite and repairing the lesions caused by the infection process. Up to now and in a general, few published papers about parasite-host interactions discuss hemocyte activities other than those related to the defense against the parasite. Therefore, the suggestion that the hemocytes may also carry out tissue-repair activities can be taken as an alternative explanation for the observation of a similar reduction in hemocytes in the two strains during the first $2 \mathrm{~h}$ after infection. These results may be considered consistent, since Araque et al. (2003) observed that a similar migration occurs in resistant and susceptible mollusk strains, especially at the beginning of the interaction with the parasite.

This decrease in the number of hemocytes detected in the first hours after exposure to $S$. mansoni has been described as a characteristic feature of B. tenagophila (Seta et al., 1996; Bezerra et al., 1997). Cochennec-Laureau et al., in 2003, when analyzing mollusks of the species Ostrea edulis, both infected and non-infected by Bonamia ostraea, observed that the number of hemocytes infiltrating tissues was higher in infected individuals than in noninfected ones and that this number increased with the intensity of the infection. This observation reinforces the idea that there is cell movement toward the infection site, and as a response to the lesion, there is a migration of these hemolymph cells toward the affected tissues.

As observed in this study, there was a significant variation in the number of hyalinocytes and granulocytes in both strains of the mollusk. However, as shown in Figures 1 and 2, between 6 and $12 \mathrm{~h}$ after exposure to the parasite, the number of granulocytes was higher in the mollusks selected for susceptibility to the infection. This fact may be related to the susceptibility feature of these individuals, that is, the defense process in this strain would be less efficient, since the granulocyte cells described in the literature as immunological active, are predominantly found in the hemolymph, instead of remaining in the damaged tissue to combat the infection.

As shown in Figure 2, there was a tendency of hemocytes to remain in the hemolymph in mollusks genetically selected for susceptibility. In the first $2 \mathrm{~h}$, there was a decrease in the number of hemocytes in the hemolymph of both strains of mollusks; this fact may be associated with the migration of hemolymph cells to the injured tissues. Two hours after the exposure to miracidia, there was a significant increase in the number of hemocytes in the hemolymph of both strains of snails. Nevertheless, after this period, there was a greater oscillation in the number of hemocytes in individuals non-selected for susceptibility to the infection and there was a predominance of these cells in the hemolymph of those individuals selected for susceptibility. This fact is quite evident in relation to the granulocytes, as shown in Figures 2 and 3.

The results obtained in this study allow us to establish a direct relationship with the concept of molecular mimetism, as described by Yoshino and Bayne in 1983. We can pro- 
pose the hypothesis of a differential migration behavior of these defense cells mediated by the recognition of the parasite as self or non-self. In both strains of $B$. tenagophila, the hemocytes, predominantly the granulocytes, migrate from the hemolymph to the lesion site, provoked by the intrusion of the parasite. However, in the snails non-selected for susceptibility, there would be a recognition of the larval forms of the parasite as non-self, which, therefore, would lead to the permanence of these cells in the damaged tissues in order to defend the snail against the parasite. In this way, a lower level of granulocytes would be found in the hemolymph, as shown in Figure 3. For the snails selected for susceptibility, it may be inferred that the larval forms of the parasite would be recognized as self due to the mimetic mechanisms of the Schistosoma. Thus, the hemocytes would remain in the injured tissue for a shorter period of time with the objective of tissue repair and would rapidly return to the hemolymph, maintaining the number of circulating hemocytes. In the snails genetically selected for susceptibility to infection by $S$. mansoni, in the 24-h period after the exposure to the parasite, the number of hemocytes in the hemolymph returned to their original number; that is, the number of the hemocytes in the snails not exposed to the miracidia. This fact has already been pointed out by Seta et al. (1996). By means of histopathological analysis, these authors observed the presence of several fragmented sporocytes in relation to fewer complete sporocytes. Therefore, in the resistant individuals, the majority of the sporocytes are dead in the interval of $24 \mathrm{~h}$. This explains the return of the circulating hemocytes to their initial number 24 $\mathrm{h}$ after the exposure to the miracidia in mollusks genetically non-selected for susceptibility.

The differential migration of hemocytes based on molecular mimetism, suggested in this study, could be associated with the presence or absence of surface receptors in these cells to excretion-secretion products released by $S$. mansoni and to physiological components in the mollusks, which may or not favor the development of the $S$. mansoni larva. These factors should be considered within the complex network of the parasite-host relationship, as previously reported by several authors (Yoshiro and Bayne, 1983; Duvaux-Miret et al., 1992; Boyle et al., 2000; de Jong-Brink et al., 2001; Vasquez and Sullivan, 2001; Bayne et al., 2001; Yoshino et al., 2001).

The results described here provide a starting point for the establishment of correlations with the mechanisms of resistance/susceptibility shown by the host species. In this way, these findings contribute to biological information leading to new studies that may support the development of new strategies to control schistosomiasis.

\section{ACKNOWLEDGMENTS}

Research supported by Fundação para o Desenvolvimento da UNESP-FUNDUNESP (SP, Brazil). The authors are grateful to CIVAP/Health (Assis, Brazil) for technical advice. A.L.D. Oliveira was supported by a fellowship from CAPES.

\section{REFERENCES}

Allegretti SM (1991). Comportamento de Biomphalaria glabrata Variante Albina e Melânica Frente à Infecção por Schistosoma mansoni. Master's thesis, UNICAMP, Campinas.

Araque W, Barrios EE, Rodriguez P, Delgado VS, et al. (2003). Ultrastructural study of the in vitro interaction between Biomphalaria glabrata hemocytes and Schistosoma mansoni miracidia. Mem. Inst. Oswaldo Cruz 98: 905-908.

Bayne CJ, Hahn UK and Bender RC (2001). Mechanisms of molluscan host resistance and of parasite strategies for survival. Parasitology 123 (Suppl): S159-S167. 
Bezerra FS, Nogueira-Machado JA, Chaves MM, Martins RL, et al. (1997). Quantification of the population and phagocytary activity of hemocytes of resistant and susceptible strains of Biomphalaria glabrata and Biomphalaria tenagophila infected with Schistosoma mansoni. Rev. Inst. Med. Trop. São Paulo 39: 197-201.

Boyle JP, Zaide JV and Yoshino TP (2000). Schistosoma mansoni: effects of serotonin and serotonin receptor antagonists on motility and length of primary sporocysts in vitro. Exp. Parasitol. 94: 217-226.

Cochennec-Laureau N, Auffret M, Renault T and Langlade A (2003). Changes in circulating and tissue-infiltrating hemocyte parameters of European flat oysters, Ostrea edulis, naturally infected with Bonamia ostreae. J. Invertebr. Pathol. 83: 23-30.

de Jong-Brink M, Bergamin-Sassen M and Solis SM (2001). Multiple strategies of schistosomes to meet their requirements in the intermediate snail host. Parasitology 123 (Suppl): S129-S141.

Duvaux-Miret O, Stefano GB, Smith EM, Dissous C, et al. (1992). Immunosuppression in the definitive and intermediate hosts of the human parasite Schistosoma mansoni by release of immunoactive neuropeptides. Proc. Natl. Acad. Sci. U. S. A. 89: 778-781.

Frandsen F (1979). Discussion of the relationships between Schistosoma and their intermediate hosts, assessment of the degree of host-parasite compatibility and evaluation of schistosome taxonomy. Z. Parasitenkd. 58: 275-296.

Mascara D, Kawano T, Magnanelli AC, Silva RP, et al. (1999). Schistosoma mansoni: continuous variation in susceptibility of the vector snail of schistosomiasis, Biomphalaria tenagophila I. Self-fertilization-lineage. Exp. Parasitol. 93: 133141.

Oliver LM and Fisher WS (1995). Comparative form and function of oyster Crassostrea virginica hemocytes from Chesapeake Bay (Virginia) and Apalachicola Bay (Florida). Dis. Aquat. Org. 22: 217-225.

Paraense WL and Correa LR (1963). Variation in susceptibility of populations of Australorbis glabratus to a strain of Schistosoma mansoni. Rev. Inst. Med. Trop. São Paulo 5: 15-22.

Paraense WL and Correa LR (1978). Differential susceptibility of Biomphalaria tenagophila populations to infection with a strain of Schistosoma mansoni. J. Parasitol. 64: 822-826.

Ratcliffe NA (1985). Invertebrate immunity - a primer for the non-specialist. Immunol. Lett. 10: 253-270.

Richards CS (1984). Influence of snail age on genetic variations in susceptibility of Biomphalaria glabrata for infection with Schistosoma mansoni. Malacologia 25: 493-502.

Richards CS, Knight M and Lewis FA (1992). Genetics of Biomphalaria glabrata and its effect on the outcome of Schistosoma mansoni infection. Parasitol. Today 8: 171-174.

Ruiz JM (1957). Esquistossomose experimental. Dados sobre a infestação experimental de Biomphalaria tenagophila (Orbigny) e Australorbis glabratus (Say). Rev. Bras. Biol. 17: 179-185.

Seta L, Magalhães LA and Carvalho JF (1996). Behavior of hemolymph amebocytes from Planorbidae in the presence of Schistosoma mansoni larvae parasitism, by inoculation of Indian ink or fracture of the shell. Rev. Saúde Pública 30: $332-340$.

Sullivan JT, Cheng TC and Howland KH (1984). Mitotic responses of the anterior pericardial wall of Biomphalaria glabrata (Mollusca) subjected to challenge. J. Invertebr. Pathol. 44: 114-116.

Vasquez RE and Sullivan JT (2001). Hematopoietic tissue allografts in Biomphalaria glabrata (Mollusca: Pulmonata) induce humoral immunity to Schistosoma mansoni. Dev. Comp. Immunol. 25: 561-564.

WHO (World Health Organization) (2008). The Control Social Context of Schistosomiasis and its Control. World Health Organization, Geneva.

Yoshino TP and Bayne CJ (1983). Mimicry of snail host antigens by miracidia and primary sporocysts of Schistosoma mansoni. Parasite Immunol. 5: 317-328.

Yoshino TP, Boyle JP and Humphries JE (2001). Receptor-ligand interactions and cellular signalling at the host-parasite interface. Parasitology 123 (Suppl): S143-S157.

Zanotti-Magalhães EM, Magalhães LA and Carcalho JF (1997). Relationship between the pathogenicity of Schistosoma mansoni in mice and the susceptibility of the vector mollusk. IV - Infectiousness of the miracidia. Rev. Saúde Pública 31: 488-494. 